\title{
Rebirth of Industrial Policy and an Agenda for the Twenty-First Century
}

\author{
Karl Aiginger ${ }^{1,2} \cdot$ Dani Rodrik $^{3}$
}

Received: 24 September 2019 / Revised: 9 October 2019

Accepted: 7 December 2019 / Published online: 6 January 2020

(C) Springer Science+Business Media, LLC, part of Springer Nature 2020

JEL Codes $\mathrm{L} 10 \cdot \mathrm{N} 60 \cdot \mathrm{O} 25 \cdot \mathrm{Q} 50$

\section{The Rebirth of Industrial Policy: Reasons and Open Questions}

After a period of decline in interest and premature predictions of demise, industrial policy is back on the scene. A variety of trends have contributed to the renewed interest. In the developing world, there has been a pushback against the market-fundamentalist approach, typically associated with the Washington Consensus. Even when growth rates have been high, economies in Sub-Saharan Africa and Latin America have experienced unsatisfactory rates of productive transformation and shortfalls in generating quality jobs in manufacturing or modern services. This has created a demand for proactive government policies to diversify and upgrade economies beyond simply freeing up markets. In the advanced economies, generalized labor market malaise and the lingering effects of the financial crisis have produced similar effects. Low growth dynamics occurred especially in the euro zone, as countries with trade and budget double deficits with a common currency struggled to come out of the crisis. The continuing decline in the employment shares of manufacturing in the USA and Western European countries and the increasing competitive threat posed by China on world markets have pushed in the same direction. ${ }^{1}$ Interest in

\footnotetext{
${ }^{1}$ While virtually all countries have experienced deindustrialization in employment terms, some have managed to maintain high levels of output at constant prices. A notable example is Germany, where the manufacturing output share has remained stable due to an increasing export surplus (after being called the "sick man of Europe" postunification). The share of manufacturing is also rather stable in Austria due to EU enlargement and its new net investment position in Central and Eastern Europe and in Ireland through tax incentives for inward-FDI combined with an effective strategy of upgrading practical skills. At the other end of the spectrum, Greece and (southern) Italy provide dramas of deindustrialization losing past advantages without achieving new ones, and the share of manufacturing in value added dropped to less than $10 \%$ in the former powerhouses France and UK.
}

Karl Aiginger

Karl.Aiginger@querdenkereuropa.at

Dani Rodrik

dani_rodrik@harvard.ed

Extended author information available on the last page of the article 
industrial policy is being further stimulated by disruptive technological change - from automatization to digitalization, industry 4.0 , and the Internet of things.

Behind many of these trends looms the imposing figure of China. China's economic growth has slowed down, but even at these more moderate rates, the country is poised to become soon the largest economy in the world. The country's rapid export-oriented industrialization and impressive manufacturing sector have played a critical role in this achievement. In the USA, China has rapidly become a bogey man. American businesses complain about inadequate market access and unfair trade practices in China. Labor advocates worry about the large footprint of Chinese exports in communities that are experiencing difficulties producing sufficient numbers of good jobs. The US national security establishment meanwhile is increasingly concerned about technology transfer to a strategic and geopolitical rival and loss of US technological edge. All these have combined to yield both a hard line against China and a desire for more robust industrial policies at home. Remarkably, industrial policy is now a favored theme at both ends of the political spectrum, from progressives such as Senator Elizabeth Warren to conservatives such as Senator Marco Rubio. ${ }^{2}$ This is a trend that is paralleled to some extent in other nations. In Germany, for example, there have been calls for more activist industrial policies both from left leaning economists like Peter Bofinger and from the conservative minister for industry Peter Altmaier. France and Germany tried to reestablish their cooperation in the EU by publishing a "Manifesto" on industrial policy. ${ }^{3}$

The debate in Europe so far has had less of a hard edge against China. The growing Chinese presence in Europe, and especially Chinese acquisitions of European firms, has led to calls for a review of competition rules. In Europe, as well as in the USA, applying "national security clauses" to prevent Chinese giants from buying firms is on the agenda. When mergers of European firms are screened by the European competition authority, "competition with Chinese mega-firms" sheltered in their own country is deployed frequently as an argument for allowing such mergers to go ahead. ${ }^{4}$ On the other hand, the EU enjoys an overall trade surplus - with very different national experiences within and outside the common currency area. With the greater salience of industrial policy objectives, there is a brewing tension between these objectives and competition policy goals.

For developing nations, meanwhile, China is both a threat and an example to emulate. On the one hand, Chinese success in manufacturing has made it more difficult for many middleincome countries to compete on world markets and has contributed to premature deindustrialization. ${ }^{5}$ On the other hand, Chinese industrial strategies are yet another powerful example of how concerted government action can stimulate rapid economic diversification and structural change. And as Chinese labor costs continue to rise, there is potentially a role for low-income, low-cost countries to fill the gap on world markets left by receding Chinese export presence.

A question of great interest is whether Africa will be able to become a supplier of manufacturing goods, with manufacturing playing a key role for "rising Africa." This continent has never had a proper industrialization experience, and many observers hope this is the time for a great leap forward based on industrial growth and exports. Is there a strategy that could produce rapid industrialization, despite forces militating in a different direction such as

\footnotetext{
$\overline{{ }^{2} \text { Warren (2019) and Rubio (2019). }}$

${ }^{3}$ Bofinger (2019), Altmaier (2019).

${ }^{4}$ See the Alstrom-Siemens case, in which the firms argued to need a merger for remaining competitive with Chinese rail equipment. The merger was rejected by the EU Commission in spring 2019. A Franco-German Manifesto for a European Industry Policy for the twenty-first century see BMWI (2019).

5 Rodrik (2016).
} 
rich natural resources endowments, political conflicts, climate change, and bad governance? For other, middle-income developing nations, the question is the role that a more modern version of industrial policy, emphasizing productive services in addition to manufacturing, can play in overcoming premature deindustrialization, middle-income traps, and failure to transition to more fully diversified economies (Table 1). ${ }^{6}$

Finally, an increased focus on societal and environmental goals is necessarily raising questions about industrial policy as it shapes the structure of economic activity more generally. In general, manufacturing has been a "dirty" sector with high carbon emissions. It is also a sector subject to strong business fluctuations, leading to short- and medium-term unemployments. On the other hand, in many countries, manufacturing is associated with good jobs and a strong middle class. Many technological solutions for cleaner production also have their origins in manufacturing, and the interface between manufacturing and services can often lead to highly paid and relatively stable employment. One can imagine the greening of industrial policy $^{7}$ or new forms of industrial policy steered by employment concerns. ${ }^{8}$ The "green new deal," which has adherents on both sides of the Atlantic Ocean (and is high on the agenda of Ursula Von der Leyen, the new president of the European Commission), is an attempt to combine these two objectives under one large rubric.

It is hard to know where these trends will lead. It is possible that a renewed emphasis on industrial policy, reinforced by the spread and growth of ethnonationalist populism, will replicate and magnify the worst mistakes of interventionism and statism from the past. This would take the form of defensive and purely protectionist strategies aimed at propping up ailing firms and national champions, while creating beggar-thy-neighbor harms on other nations. Or we could see the rise of new, more nimble forms of collaboration between the government and the private sector that draw on the lessons of the past and reorients them towards new challenges. Whatever the future direction, we can probably safely say that the renewed interest in industrial policy is not a short-term phenomenon. Industrial policy will be with us in the years ahead.

The question before us, therefore, is what shape industrial policy should take in this period of disruptive political and technological change. How can policy makers craft an industrial policy that is future- and welfare-oriented, which not only mitigates market failure, but also addresses society's most important social and environmental challenges, without stroking national chauvinism.

Four of the transformations that are needed are clear from the outset. First, industrial policy can no longer be about industry or manufacturing per se. Employment de-industrialization is virtually inevitable in middle-income and advanced economies alike. As the world economy turns increasingly towards services, it is clear that we will need a conception of industrial policy that addresses the need to nurture and develop modern economic activities more broadly, including but not limited to manufacturing. The appellation "industrial policy" may be even misleading insofar as it clouds this broader mission. Other alternatives such as "productive development policies," "structural transformation policies," or "innovation

\footnotetext{
${ }^{6}$ China's investment in Africa is on the one hand welcomed, as "they do not preach" like the European, meaning that the former colonial powers set conditions for their support on European values or democracy, but also criticized as it uses own labor, neglects ecological reasons, and all the infrastructure investments support primarily "resource grabbing" or to export own low-quality goods neglecting the necessity to stimulate intraAfrican trade.

7 Aiginger (2013a, b)

${ }^{8}$ Rodrik (2014) and Rodrik and Sabel (2019).
} 
Table 1 Shares of manufacturing in GDP

\begin{tabular}{|c|c|c|c|c|}
\hline & \multicolumn{2}{|c|}{ Nominal value added in manufacturing } & \multicolumn{2}{|c|}{ Real value added in manufacturing } \\
\hline & 1995 & 2018 & 1995 & 2018 \\
\hline & \multicolumn{4}{|c|}{ Percentage shares in GDP } \\
\hline Austria & 17.9 & 16.6 & 15.8 & 18.7 \\
\hline Finland & 22.2 & 15.3 & 13.9 & 15.8 \\
\hline France & 14.9 & 9.9 & 10.6 & 10.3 \\
\hline Germany & 20.6 & 20.8 & 19.3 & 21.5 \\
\hline Netherlands & 15.3 & 10.8 & 11.3 & 10.9 \\
\hline Sweden & 19.9 & 13.8 & 12.5 & 13.6 \\
\hline UK & 15.7 & 8.9 & 12.6 & 8.1 \\
\hline EU 28 & 17.7 & 14.5 & 14.7 & 14.6 \\
\hline Euro Area & 18.0 & 15.4 & 15.2 & 15.7 \\
\hline CEEC & 19.7 & 18.9 & 14.1 & 19.5 \\
\hline Sub-Saharan Africa & 15.5 & 9.7 & 12.8 & 9.8 \\
\hline USA & 16.3 & 11.5 & 12.0 & 11.3 \\
\hline China & 32.6 & 29.4 & 23.4 & 26.2 \\
\hline World & 19.4 & 16.3 & 12.8 & 15.3 \\
\hline
\end{tabular}

USA 2016. CEEC = Bulgaria, Croatia, Czech Republic, Estonia, Hungary, Latvia, Lithuania, Poland, Romania, Slovak Republic, Slovenia. Sub-Saharan Africa = Angola, Benin, Botswana, Burkina Faso, Burundi, Cabo Verde, Cameroon, Central African Republic, Chad, Comoros, Congo Dem. Rep., Congo Rep., Cote d'Ivoire, Equatorial, Guinea, Eritrea, Eswatini, Ethiopia, Gabon, Gambia, Ghana, Guinea, Guinea-Bissau, Kenya, Lesotho, Liberia, Madagascar, Malawi, Mali, Mauritania, Mauritius, Mozambique, Namibia, Niger, Nigeria, Rwanda, Sao Tome and Principe, Senegal, Seychelles, Sierra Leone, Somalia, South Africa, South Sudan, Sudan, Tanzania, Togo, Uganda, Zambia, Zimbabwe. Source: Eurostat, World Bank (WDI), own estimates.

policies" do exist. We have stuck with the traditional terminology here, even though these other labels may be more appropriate for what we have in mind.

Second, the industrial policy of the future is unlikely to look like the economist's traditional conception of it: top-down policymaking, targeting pre-selected sectors, and employing a standard list of subsidies and incentives. This kind of industrial policy may have been common in certain countries - Japan, South Korea, Taiwan, and some European countries - and has produced some success, but increasingly, the emphasis is different. The contemporary conception and practice of industrial policy is much less about top-down incentives and much more about establishing a sustained collaboration between the public and private sectors around issues of productivity and social goals. This kind of dialog eschews an ex ante selection of activities to promote or policy instruments to utilize. It focuses instead on engineering an appropriate institutional setting within which the collaboration can best bear fruit. Government policies, as well as firm strategies, are the outcome of this process. These policies and strategies are viewed as provisional at the outset, to be continuously monitored and revised in light of outcomes.

Third, industrial policy can no longer be an isolated policy, developed on its own and competing with competition, regional, and other growth policies (Aiginger 2014). As we mentioned above in the context of Europe, the goals of competition policy and industrial policy are often in tension or viewed as such. Competition policy targets mainly consumer welfare, while industrial policy is concerned with productive, dynamic industries. In the long run, the two goals ought to be consistent, but in the short run, maximizing consumer benefits may lead to different priorities than productive diversification and dynamism. Similarly, there has often been not only considerable overlap but often also a conflict between regional policies 
and industrial policy without an explicit division of labor or coherent coordination. To what extent, for example, should industrial policy target communities and areas left behind and take the form of "place-based" policies? And to the extent that they do, what are the respective roles of propping up declining, traditional industries versus encouraging new industries? Such questions will have to be confronted more systematically.

Fourth, support of structural change and productivity growth can no longer serve as a policy goal without any consideration of the direction of technological change. ${ }^{9}$ In industrialized countries, the current bias of technical progress towards labor saving must be questioned, as it is neither natural nor conducive to a shift to lower, greener, and healthier growth. Steering technological change in a direction that is friendlier to environment and labor must be a key element of new industrial policies. In emerging economies, the question is whether industrial policy should copy leading economies or instead look for approaches better suited to the own countries' stages of development, as well as focus on new priorities such as supporting vulnerable groups, gender equality, reduced fossil energy use or the development of green technologies for new types of agriculture, housing, and transport. ${ }^{10}$

\section{The Goals and the Content of this Special Issue}

To help us think about these questions, we invited contributions from distinguished researchers with significant experience in the broadly defined field of industrial policy, as well as some specialists for regions of rising importance and others for countries in which industrial policy has been prominent or successful in the past. The authors address two broad sets of questions. First, how do we properly evaluate industrial policy efforts of the past, and second, what are some desirable future paths for the evolution of policies in this domain? In other words, the papers we have assembled speak both to the positive and normative aspects of industrial policies. And they add to existing knowledge and calls for a transformation of policy.

We now provide a quick discussion of these nine papers, stressing their distinctive contributions and their inter-relationships.

Nathaniel Lane provides a broad overview of the expanding new empirical literature on the consequences of industrial policy. There is a fair number of surveys in the literature to be sure. ${ }^{11}$ What is distinctive in Lane's piece is the emphasis on methodological considerations in drawing inferences about the causal effects of industrial policy. The early evidence concentrated on infant industries in developing counties. A key problem with these studies is that policy is typically endogenous: governments do not distribute their incentives randomly across activities but pick and choose for a reason. Hence, these cross-country or industry-level studies are difficult to interpret since they typically regress one endogenous variable (some measure of economic performance) on another (some measure of the incidence of industrial policy). These problems are often confounded by poor measurement of incentives. The evidence that such studies yield, as Lane points out, is not merely "mixed;" it is "vacuous."

\footnotetext{
${ }^{9}$ The necessity to shift from a focus on the growth of labor productivity to resource and energy productivity is called a "redirecting" technical progress by Aiginger (2016).

${ }^{10}$ For the definition of a systemic industrial and innovation policy (SIIP) see Fig. 1 in the Appendix.

${ }^{11}$ See for example Rodrik (2004), Aiginger (2007, 2014, 2017, 2019a); Aghion et al. (2014); Mosconi (2015); Aiginger (2014), Aiginger et al. (2013), Aiginger and Firgo (2017); Stiglitz et al. (2013); McGillivray (2004); Wigger (2018); Pianta et al. (2016); European Commission (2010).
} 
A new wave of empirical work has paid much closer attention to questions of causal inference. These studies, using contemporary econometric methods, have rapidly expanded our knowledge on the richness and complexity of the effects of industrial policy. Some of them use natural experiments created by historical accidents - such as the import-substitution possibilities created in France by the blockade on British shipping during the Napoleonic Wars. Others exploit exogenous changes in the regional application of policies - such as the inclusion and exclusion of some British regions from EU state aid rules arising from shifts in EU-wide regulations. Yet others use regression discontinuity or difference-in-differences designs. There are also structural industrial organization models that build the behavior of firms from the ground up and develop explicit industry counterfactuals. Though it remains difficult to draw general conclusions from this newer literature, many of these studies have demonstrated that industrial policy is effective in stimulating activities that are subject to production or investment incentives. But much also depends, unsurprisingly, on the policies used and the institutional context. But the marriage of new empirical techniques to the perennial question "does industrial policy work?" promises to yield more insights in the future as the literature develops further.

Given the importance of institutional settings, it is appropriate to focus on country contexts, and five of our papers do exactly that.

Fred Block, Matthew R. Keller, and Marian Negotia focus on the USA and the Advanced Manufacturing Institutes set up under the Obama administration specifically. The USA is an interesting case in the present context, since the conventional view is that the American economy is the most market-oriented among wealthy countries and that American policy makers have little patience for industrial interventions. Yet, this has never been correct. As the authors have demonstrated in their previous work, ${ }^{12}$ industrial policy has been common at the federal and state levels.

Advanced Manufacturing Institutes are a new direct support program of the US government, comprising 45 institutes across the country that span networks of businesses, universities, and laboratories. The central idea behind the initiative was that each institute would serve as the center of a local cluster of firms and expertise revolving around a particular technology. These institutes are a continuation of a tradition of state-sponsored collaborative innovation and production that go back at least to the 1970s. An early evaluation by Deloitte discussed by the authors shows the institutes have met many of the initial goals, including network connectivity, reduced search costs for identifying partners, increasing capacity to solve collective action problems, enhanced technology roadmaps, and investments in workforce development. The paper also highlights the role of network failures in providing a rationale for government leadership and intervention. Innovation and production today typically require sustained collaboration among multiple entities - suppliers, final assemblers, technology labs, universities, and labor training facilities. There is an ever-present risk that firms will not be able to locate the competent and trustworthy partners they require to complete these complex chains of collaboration. Akin to the concept of coordination failure more familiar to economists, network failure may prevent potentially productive and profitable clusters from emerging. US policy makers have been aware of this problem and manufacturing institutes have been one institutional response. They allow the government to bring different partners together, coordinate behavior, certify competence and trustworthiness, and pre-empt concerns about theft of intellectual property.

${ }^{12}$ Block and Keller (2011). 
The contribution by Pierre Buighes and Elie Cohen chronicles analyzes the different phases of French industrial policy. Unlike the USA, France is a country known for its extensive forays in industrial policy. The "autonomous" French approach was known for its optimism regarding sectoral planning and predictability, and France had enjoyed a strong industry with a leading industrial and military sector, then extending to space, aircraft and high-speed trains. French industrial policy has been successful on the whole until the adoption of the European single market, especially during the De Gaulle-Pompidou years (1958-1974). The success was the product of both internal and external elements. Externally, this was a period when the international environment allowed "room for maneuver of national governments." Internally, this was "a moment of rare coherence between macroeconomic objectives of reconstruction and development [and] meso-economic objectives of industrial specialization." Due to the focus on technology, Buighes and Cohen describe French policy as "high-tech Colbertism," which is reminiscent of the "mission-oriented" approach discussed later in this issue. Large state projects were based on a technological bet, with the risks shouldered jointly by the state and business. They required "organic cooperation with the industry." They yielded results thanks to the French state's practice of "offensive protectionism," availability of public financing, the utilization and transfer of the results of public research, and support through public procurement. Contrary to conventional wisdom, the paper argues the French state was quite willing and able to kill white elephant projects when the success of a sector a whole required it. Examples are national technologies such as graphite-gas in nuclear power, Diamant in space exploration, and Aerotrain in railways. But success turned, in the authors' words, into an "ultimate failure." The deepening of European integration, and the creation of the euro in particular, has rendered industrial policy in one country unworkable. Its extension on the European scale, meanwhile, proved unviable because it was compatible neither with German ordoliberalism nor with British liberalism. The inability to use the currency for competitiveness and the dismantling of the interventionist apparatus resulted in France becoming the "worst dropout" in terms of value added, jobs, and export market shares in manufacturing.

Contemporary French industrial policy is based on three elements: a territorial approach supporting regional competence centers, targeting sectors like generic technologies in biotech and sectors with French competitive advantage, and improving non-cost competitiveness mainly through a tax research credit but also through a payroll subsidy. Upon taking office, President Macron took a number of horizontal measures, cutting corporate taxes, extending innovation incentives, strengthening education efforts in deprived neighborhoods, and improving vocational training. But the French system is complex and bewildering. To provide an example, there exist 120 mechanisms for starting a company and 71 poles of competitiveness. While the profile of industrial policy is once again on the rise in both France and the EU at large, the coherence and coordination of the earlier era are yet to be re-established.

Jan Fagerberg and Gernot Hutschenreiter present three case studies on Finland, Sweden, and the Netherlands, all part of the Northern European welfare-state model with a rather strong manufacturing base. They focus more narrowly on innovation policies, which they characterize as a fusion of science, technology, and industrial policy. Technological dynamics are created through five essential processes: knowledge, skills, innovation, finance, and institutions, which are considered as complements rather than substitutes. While the impact of innovation on growth has a long tradition in economics, its ability to tackle societal challenges, such as humans' relationship to nature, has only recently been acknowledged. Innovation performance can be measured by the European Innovation Scoreboard (EIS), a composite 
measure including a broad set of indicators. The three countries discussed by the authors rank as numbers 2,4 , and 5 in this evaluation.

All three countries experienced rather deep crises in the 1990s and tried to respond by upgrading innovation and restructuring institutions. Finland transformed itself from a capitalintensive economy to an information technology star but was then hit by the decline in market power of its dominant firm. Subsequently, it restructured innovation-related institutions, emphasizing basic research and Research Innovation Councils (RICs). The Netherlands had been a late-comer as a welfare state and changed from a defensive industrial policy to market orientation and a top-sector approach. It emphasizes self-organizing PPP by Top Teams, while sticking to its cooperative social "Polder" model. Whether societal goals are pursued effectively is reported to be "an open question." Sweden changed to a high technology path after its loss of cost competitiveness in the 1990s. It acknowledged that its comprehensive welfare state could be sustained only as a leader in innovation and R\&D. R\&D ratios had been top for at least a decade. They are now slightly decreasing, due to the takeover of multinational firms, e.g., in pharmaceuticals, but Swedish MNEs also profit from their increased research abroad. To vitalize innovation, the Swedish innovation agency Vinnova invited firms, universities, and other actors to develop a strategic innovation agenda including strategic innovation organization (SIO). Challenge-driven and mission-oriented programs are now fostering cooperation programs for smart cities, life science, and new materials.

The common element in all three cases is institutionalized policy coordination with the prime minister playing a central role. This setup enabled a certain degree of policy coherence and implementation. When, as in Finland, the coordination system extended to non-governmental stakeholders, the focus could expand to the entire national innovation system. Nevertheless, the ability to set a direction - to create a vision of where to go and pushing societal goals - is no easy task and may require a better definition of goals and new indicators to monitor them.

Murat A. Yülek, Kwon Hyung Lee, Junggsuk Kim, and Donghyun Park focus on the automobile sector in South Korea and Turkey. South Korea has a long and successful track record of industrial policy, while policies and performance in Turkey have been patchier. The two countries started under similar conditions, with industrial policy motivated by infantindustry arguments. But export orientation was much stronger in Korea from the outset, while Turkish industry struggled to develop under import-substitution policies. The South Korean government pushed for international competitiveness alongside a drive for indigenous technology, local industrial capabilities, enhanced human resources (including KAIST, Korea Advanced Institute of Science and Technology), domestic entrepreneurship, and local branding. Eventually, Korea became a leading world automobile manufacturer. Turkey's market share is now not only smaller but also more fragmented. Indigenous technology, local content and globally known brands like Hyundai and Kia are driving success in Korea, while Turkey's automobile sector works under international licenses. Korea runs a large export surplus, while Turkey has deficits or small surpluses in automobile trade.

The authors underline six key differences between Turkey and South Korea: (1) the drive to build indigenous technological and industrial abilities, (2) the presence of industrial entrepreneurs, (3) a local branding effort, (4) the timing of export orientation, (5) appropriate policy design, focus and vigor, and (6) a wider range of industrial policy tools, technology assistance and public procurement. The difference between the two countries is the result not of the presence or absence of industrial policies but of differences in what the authors call "state capacity." This is an elusive concept but denotes the state's ability to steer business, entrepreneurship, and investment in socially desirable directions. 
Alan Gelb, Vijava Ramachandran, Christian J Meyer, Divyanshi Wadhwa, and Kale Navis investigate strategies for industrial catch-up in Africa. Sub-Saharan Africa is a region of the world where state capacity remains particularly scarce. A critical question is whether countries in this region can replicate the success in manufacturing that other countries achieved. Now that China and other Asian countries have lost their labor cost advantage, it would seem that African countries could play a larger role in global manufacturing. Building on the World Bank's enterprise survey data and using panel econometric analyses, they document a critical roadblock: industrial labor costs remain high in Africa relative to productivity, which does not rise enough. This suggests the need for alternative or complementary strategies for most countries in the region. These may be based on natural resources or regional integration or efforts to improve the business climate and upgrade skills to the point that competitiveness improves enough to sustain industry without resorting to low wages. Balanced strategies are more likely to be viable than the exclusive orientation on export-oriented industrialization a la East Asia.

Africa is highly heterogenous, and different countries might need different strategies. One group in Africa comprises solidly middle-income countries such as South Africa and Botswana. Here, labor costs are very high, the existing industrial sector is highly capital-intensive, and unemployment remains between 20 and $30 \%$. Since lowering wages is politically unacceptable, low-cost manufacturing seems an unlikely path for this group. A second group includes low and lower middle-income countries like Kenya, Tanzania, and Senegal. These are coastal countries, politically relative stable, and with a strong business sector. They could be the vanguard in a take-off via manufacturing. A third group includes low-cost countries such as Democratic Republic of Congo, Ethiopia, and Malawi. Some of these countries, however, are richly endowed with natural resources, suffer from poor governance, and are unlikely to attract much manufacturing investment. The authors focus on Ethiopia in particular, a country that has received much attention as a destination for Chinese and other manufacturing investment. They note that "the cost of industrial labor in Ethiopia would be comparable to that of China in the 1980s and only about one quarter of that in China today." Yet industrial employment expansion has been low, and manufacturing has barely kept pace with Ethiopia's impressive economic growth over the last decade (which has been led by agriculture and services). Ethiopia' industrial promotion policies have rested on three legs: (i) an effort to increase agricultural productivity and boost food security, (ii) a range of incentives for investors, and (iii) measures to hold down the costs of essential inputs and boost their long-term supply. The use of industrial parks has been a primary means for facilitating manufacturing, by reducing the cost of entry to foreign investors. ${ }^{13}$ The authors judge that it is too early pass verdict on Ethiopia's industrial development drive. As they put it, "domestic value chains are still embryonic, and political unrest could unsettle investment in the manufacturing sector if repeated on the scale seen in 2015 and 2016. Even with some of the cheapest electricity in Africa, grid failures and power outages are frequent."

Justin Yifu Lin and Yong Wang turn to countries not starting from low levels but concerned about getting stuck at what has come to be called the "middle-income trap." Out of 101 countries defined as middle-income counties in 1960, only 13 had reached the status of a high

\footnotetext{
${ }^{13}$ There have been also notable coordination efforts to develop leather and textile industries. In leather, for example, the government has founded the Leather Industry Development Institute (LIDI), coordinated the development of human capital resources with universities and vocational schools, and facilitated public-private sector collaboration, in addition to providing direct financial incentive.
} 
come country by 2008 . Whether such a trap exists or not, it is clear that sustained economic development requires changes in government strategy along the path of development. Countries beyond the early stages of industrialization need to move into more sophisticated lines of economic activity, both in industry and services. What worked earlier may no longer work now, especially given the global trend towards premature deindustrialization. ${ }^{14}$

Lin and Wang provide a theoretical framework to help us understand key features of this transition. Their story of the middle-income trap emphasizes the essential role played by "producer services"-inputs such as finance and business services into more advanced manufacturing. When countries are at low levels of income and specialize in basic manufacturing, they posit that the local availability of producer services is not a constraint. But at later stages of development, with more advanced production structures, these production services become important. A second key feature of their framework is these producer services are subject to scale economies. Hence, the economy has multiple equilibria. Government coordination - industrial policy - may be needed to ensure the availability of domestically produced producer services at sufficient scale and low enough cost. Possible policy instruments include the provision of investment subsidies to producer services and/or merely "fueling optimism in growth forecasts for the economy." The presence of multiple equilibria may help explain why some countries escape the middle-income, but others with similar conditions do not: pure luck or the availability of pro-active government coordination selects one or the other of the equilibria.

Lin and Wang's analysis is motivated in no small part by China. Some predict China will follow South Korea and Taiwan to become a rich country. But as their paper points out, there is no shortage of obstacles: aging, uncertainty about the direction of reforms (in land, capital, labor), ongoing corruption, rising inequality, financial risks, and inadequate innovation capabilities. Geopolitical tensions, trade war with the USA, and growing authoritarianism could also play an adverse role. In this context, the authors' focus on the role that industrial policy can play is potentially an important contribution. The strategy proposed in the paper of subsidizing producer services and reducing their entry barriers could complement the ambitious plans for China 2030 and the One Road One Belt Initiative. It also provides an added perspective for other countries engaged in reforms in education and governance as they advance towards the technology frontier.

Eduardo Fernandez-Arias, Ricardo Hausman, and Ugo Panizza start from the premise that governments should not presume they know where the market failures lie. Too much confidence from the outset results in misguided policies - in public failures. But neither should governments give up in the face of uncertainty and inadequate information. Wellcrafted institutions can help governments discover where the problems and failures lie. Analyzed from this perspective, industrial policy is transformed from its traditional conception - of a set of sectoral priorities coupled with policy instruments - to a new approach of establishing search processes that yield clues about the problems and their solutions endogenously.

The paper illustrates this new approach in the context of development banks. Traditional public banking functions such as subsidized lending for SMEs, agriculture, or housing may be desirable for social or political economy reasons such as cushioning unemployment or fighting inequality, but they do not directly facilitate the emergence of new, highly productive sectors. Activities of development banks should focus directly on increasing productivity, especially on

${ }^{14}$ Rodrik (2016). 
building productive capacities and stimulating positive structural change. "Smart development banks" should engage in search for nascent economic activities whose take-off is blocked by market or government failures. This is intelligence gathering and dissemination instead of simply providing credit on the blind assumption that the most serious market failures are in the credit markets.

The authors carry out a survey of development banks to show that existing practice is very far from what the authors propose, though these banks sometimes fall into that role by happenstance. For example, one bank manager "described a case in which his bank was asked by the government to rescue a cooperative firm that had lost access to credit. At the beginning, this was pure political lending. The only objective of the government was to avoid job losses. However, by working with this cooperative, the bank acquired substantial knowledge about financial challenges that are specific to cooperative firms and this knowledge is now allowing the bank to lend to cooperative firms, which are usually ignored by private banks." The authors conclude that development banks can be reoriented to exploit the complementarities between their lending and intelligence gathering on productive activities functions. They should see their role as transmitting information to the relevant agencies on market as well as government failures. The authors' survey shows this may be a long road, but one well worth embarking on.

Mariana Mazzucato, Rainer Kattel, and Josh Ryan-Collins advocates - in the final paper in the special issue - move away from the market failures approach. The authors argue instead for a mission-oriented approach, focused as much on creating and shaping markets as on fixing market failures. They consider "grand challenges" such as the United Nation's sustainable development goals, the European Union Horizon 2020 research and development program, the WWWforEurope project, and the UK's 2017 Industrial Strategy White Paper. These challenges are necessarily cross-sectoral; they require stimulating demand and improving expectations of firms and investors in a Hirschmanesqe fashion. Meeting them, they argue, requires a new toolkit that goes beyond fixing market failures. The traditional economic approach, they remind us, would not have produced the kind of market creating and mission-oriented paths of innovations such as the Internet and nanotechnology. The point is to transform the landscape rather than to fix localized problems.

To provide guidelines for how this work can be done, Mazzucato and her co-authors outline what they call the ROAR framework. The framework involves strategic thinking on the desired direction of travel (which road to take), the structure and capacity of public sector organizations, assessment of the way in which public policy is carried out, and the incentive structure for both the public and private sectors (risks and rewards). They emphasize the need to articulate well-defined goals or "missions" focused on solving important societal challenges. Through such missions, policymakers have the opportunity to determine the qualitative nature of growth. Strategic public investments across many different sectors open up new industrial landscapes, to be developed further by the private sector. Cross-sectoral learning and increased macro-economic stability are the by-products.

This rich collection of papers brings together expertise from four continents - from the most advanced countries to countries at the low end of income dominated by agriculture and resource extraction. The papers vary in scope and depth; some concentrate on specific industries, others compare countries, and yet others open up new ways of thinking about old problems. We believe they collectively provide a useful assessment of not only where we are in industrial policy but also where we should be heading, the topic we will address in the next section. 


\section{Industrial Policy for the Twenty-First Century}

Building on the reasons for the rebirth of Industrial policy and the results and suggestions of the nine papers, we will now hazard ten general principles and conclusions. ${ }^{15}$

\subsection{Manufacturing Remains Crucial for Growth and Well-Being}

Even though employment in manufacturing is likely to continue shrinking in middle-income and advanced economies, manufacturing remains crucial for development and well-being. Technological progress is specifically strong in manufacturing, and thus, a large manufacturing sector increases the chances for better living conditions of citizens and the international leverage of a country. And in view of the centrality of structural change, industrial policy is at its core of economic and social policy. No country can overcome poverty or change its relative income status - from low to middle income, or from middle to high income - without structural change and upgrading of manufacturing. Equally, the "decline of nations" is often related to missing structural change, to premature de-industrialization, or to overreliance on inward investment and foreign technology.

\subsection{Industrial Policy Has to be Systemic, Not Isolated, or Delegated to Specialists}

Industrial policy should not be an isolated policy that stands in conflict with other policy strands like competition policy, trade policy, regional, or tax policy. Successful industrial policy maximizes synergies with other partial policies. It has on the one hand to contain sectoral elements, defining important sectors for a country today or ones that expected to be important in the future but on the seconds hand support horizontal activities shaping business conditions. Sectoral policy should use the drivers of a high road strategy, like innovation, education, and sustainability, and horizontal policy should give a higher priority to key sectors. This combination could be labeled matrix-oriented industrial policy, since rows sketch sectors to be prioritized and columns policy instruments especially relevant in these sectors. ${ }^{16}$

Industrial policy should also not be delegated to special agents, ministers, and EU commissioners alone. It should be the task of the government as a whole, with the prime minister or the Head of the EU Commission in the driver's seat. The leading agents and their teams have to report and listen to parliament, citizens, experts, and firms.

\subsection{The Optimal Scale of the Industrial Sector Depends on Capabilities, Ambitions, and Preferences}

It makes no sense to set targets for the trade surplus or the share of manufacturing, as was done by the EU in a communication that calls for regaining a $20 \%$ share in GNP. The size of manufacturing or any other technologically advanced sector has to be in line with goals, strategy, resources, and living conditions. Policy distortions are in the form of protectionism (to "bring manufacturing back") and subsidization of fossil energy at the cost of nature and the environment risk the return of protectionism, trade wars, and ultimately lower social standards and wages.

${ }^{15}$ Definitions of industrial policy see Table 2 in the Appendix.
${ }^{16}$ Aiginger and Sieber (2006). 
The participation of workers, farmers, and citizens in decision making is important, both in emerging and industrialized countries, even if there are large differences across societies and stages of development. Social partnerships, through which trade unions and other representatives of employees can participate in upgrading products and skills, should be ventured, maintained, or adapted to changing societal needs. Lobbying to extend the lifetimes of declining and dirty industries has to be curbed by government. Social media, NGOs, and citizens should be invited to shape the policy agenda and prevent polarization by populists.

\subsection{Industrial Policy Has to Take the High Road}

Industrial policy for industrialized countries should follow a high road strategy that enables structural change within manufacturing. ${ }^{17}$ Manufacturing should not be understood as a narrowly defined sector but as an activity with blurred boundaries towards industry-based services and many input and output relations to all sectors in the economy, including the public sector. ${ }^{18}$ A high road strategy has to support quality and sophisticated products and develop and apply new technologies including the Internet of things and artificial intelligence. Facilitators of an ambitious industrial policy are excellence of tertiary education at universities or advanced high schools, an innovation system fostering radical innovation and top clusters. Low costs and standards, subsidies for ailing industries or national champions, import protection, and subsidies for fossil energy or nuclear energy are detrimental to a high road strategy, as is the old definition of cost competitiveness.

Industrial policy for developing countries has to focus on the eradication of poverty and the transition from low to middle income country. It may not initially be a high road strategy; however, it should be kept in mind that there are development traps such as overreliance on resources and cheap labor or a specialization in products with low income elasticity. Industrial policy in emerging countries should not only foster own efforts, complementary endogenous technologies, and some sectoral or regional planning but also reflect awareness of possible premature deindustrialization. Rising incomes will change the sectors and activities that are internationally competitive. The level and types of education and innovation will change, as will gender relations. The overuse of nature, a high population concentration and urbanization, which leaves agricultural regions behind, has to be prevented, not least since this is one source of disruptive migration.

\subsection{Redirecting Technical Progress and Preparing for Less Growth}

Today, technical progress is far from neutral; it primarily saves on labor, rather than capital, resources and energy. This extends to the overwhelming majority of policy recommendations of international organizations and policy priorities of national governments and the European Commission. This bias makes high growth mandatory if employment is not to decrease. This asymmetry is not "natural" or exogenous in the sense that technical innovations favor labor productivity, but it is policy-made. Labor is expensive in part since the bulk of taxes is levied on labor. Pollution is not taxed according to its negative impact on welfare, neither is transport on highways, air traffic, and ships. Fossil energy is subsidized and capital costs have been held

\footnotetext{
$\overline{17}$ Reinstaller and Reschenhofer 2019 and Reinstaller and Unterlass 2019.

${ }^{18}$ A dressing, a wider defined manufacturing sector, embedded in many input and output relations and value chains, mitigates the old problem, which the term industry has been used in Europe traditionally for manufacturing (plus maybe mining, electricity and construction), while the term industry has been used in the USA for all sectors of the economy including services.
} 
down specifically since the financial crisis, fostering tangible investment. Therefore, redirecting technical progress not only improves welfare and reduces the growth necessity but also corrects the bias in technical progress, created by public failure and distorted incentives.

\subsection{Societal Goals Should Be Paramount, Moving Beyond the Correction of Market Failures}

Industrial policy has to be driven by societal goals. Correcting market failures, whether they be static (monopoly, provision of public goods) or dynamic (path dependency, neglect of the distant future and lack of international cooperation) is important, but the goals of industrial policy are wider, including market shaping, mission orientation, and providing new basic technologies.

Government should only intervene if there exists a long-run interest, ${ }^{19}$ not for the short term. Its goals and instruments should be communicated with citizens, since the success and demise of industrial policy leads to successful clusters or forgotten regions. Regions with decreasing populations and underinvestment in infrastructure - together with inequality, unemployment, stagnant incomes and losses due to hyper globalization-are hotspots for populism and a threat to liberal democracy.

Societal goals involve climate, health, poverty prevention, good-job creation, and the reduction of inequality. Societal goals can be monitored by sustainable development indicators or beyond-GDP schemes. Scoreboards and success evaluation, including the European semester, should rate innovation and well-being. The perspective of international organization as well as credit ratings by semiprivate financial watchdogs should gradually converge to similar goal sets even if the perspective and the degree to which a goal can be attained will differ. New definitions should be used for competitiveness, structural policy, and country performance.

\subsection{Search Process in an Unknown Territory}

Industrial policy is a search process; it requires embeddedness without allowing hostagetaking. The more ambitious the goals of industrial policy are, the less government knows about the techniques available to solve them. Industrial policy is therefore a search process in unknown territory, which should be open to new solutions, experiments, and learning. Therefore, government and business should engage in an intensive dialog, screening decentral information. However, government has to be aware that the information given by firms may be biased in their particular interest and find ways to parse important information from the egoistic advice of incumbents.

\subsection{Asian Countries Demonstrate How to Combine Planning with Market Forces}

Industrial policy can be very different, ranging from providing only general business conditions to strategies close to top down planning. The East Asian countries tend to prioritize sectors and define important technologies. Firms following these strategies get cheaper credits and higher subsidies. Many of these countries have been successful, such as Korea, China, and Taiwan. But all these countries also included market forces, such as open economies, special zones, or favorable conditions for multinational enterprises. This is what distinguishes them

${ }^{19}$ Aghion et al. (2014). 
from Soviet planning, unsuccessful attempts in Turkey and the limited success of Japan after it came close to the technological frontier.

\subsection{Industrial Policy Can Mitigate Populism}

Populism and nativism - in all their different manifestations in the USA, Europe, or emerging countries - are related inter alia to Rust Belts, industrial regions losing dominant firms, and districts losing their populations through emigration while averse to new migrants. ${ }^{20}$ Finally, these "forgotten regions" are becoming less and less attractive to new firms. Industrial policy has contributed to their demise by favoring clusters, industrial poles, and the internationalization of production and networks. Regions facing such downward spirals must develop a new strategy. This could include the following: inviting former citizens to return and apply their enlarged skill sets back home, improving infrastructure, favoring new firms that do not require economies of scope or scale, stressing teleworking, and providing new lodgings that integrate different generations. A combination of regional, industrial, and social policies will therefore also reduce one of the root causes of populism by increasing well-being in not only disadvantaged regions, but also centers and metropolises. A strategy along these lines, focused on creating "good jobs," is outlined in Rodrik and Sabel (2019).

\subsection{An International Forum for Industrial Policy Shaping Responsible Globalization}

We propose that an annual international forum be established for industrial policy to be discussed with political leaders, civic organizations, and firms. Industrial policy can and will be different across countries in different continents and stages of development, but there are a multitude of positive and negative spillovers between countries and there is a wide scope for mutual learning. This includes trade and investment rules, secure property rights, social standards, and the promotion of energy efficiency and renewable energy. An annual global forum could enable parallel national strategies to stop subsidies for fossil energy and large-scale agriculture, as well as a shift from turbo-globalization to responsible globalization. ${ }^{21}$ It should discuss how the losers of globalization and technological change can be compensated or even better empowered to switch to better jobs, thus reducing a root causes of populisms, conflicts and disruptive migration waves. The forum could discuss how military spending could be curbed, development assistance improved, and resource grabbing prevented. It would probably make sense for Europe to take the lead, given its strength in manufacturing and its more ambitious attempts to include social and ecological issues in industrial policy. However, the lead could gradually be shared and the forum could become a partnership with Africa, emerging countries in Asia and South America and of course also eventually rotate with China and the USA.

Summarizing, industrial policy is a systemic approach that coordinate innovation, regional policy, and trade policy, with manufacturing at its core, while affecting upstream and downstream industries, sectoral change, clusters, and networks. It should be steered by societal goals that lead to sustainability and responsible globalization. Extending far beyond the correction of market failures, it is a search process into the unknown that not only profits from a dialog with experts, interest groups, and citizens but must also avoid hijacking by special interest groups and populism.

\footnotetext{
${ }^{20}$ Aiginger 2019b.

21 Aiginger and Handler 2017.
} 


\section{Appendix}

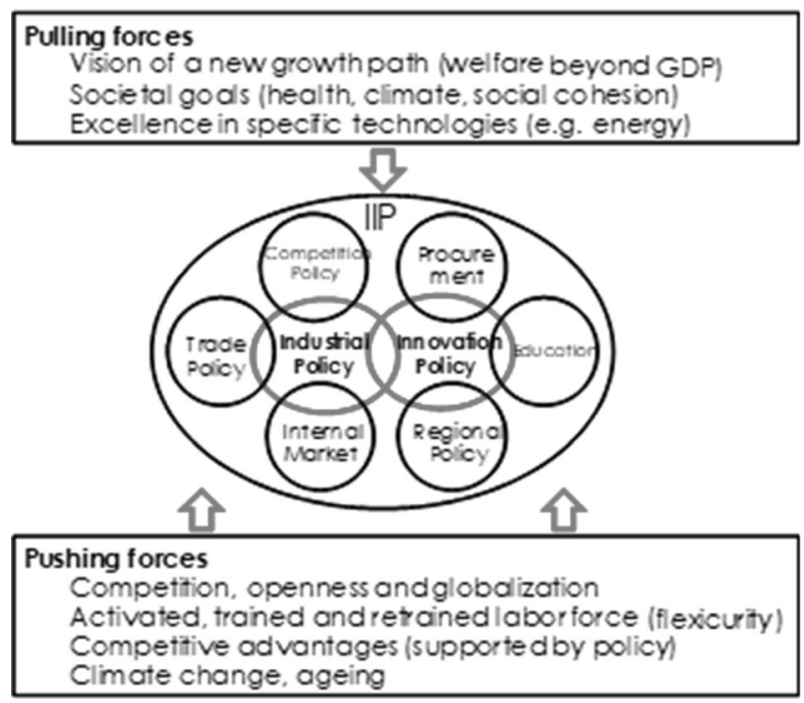

Fig. 1 Structural industry and innovation policy (SIIP). Source: Aiginger, K. (2015), Industrial Policy for a sustainable growth path, in Bailey, D., Cowling, K., Tomlinson, P., New Perspectives on Industrial Policy, Oxford University Press, pp. 365-394

Table 2 Definitions of industrial policy: an overview from past to present

Curzon Price, V. (1981), "Industrial Policies in the European Community".

Adams, G.,Klein, L.R. (1983), "Industrial Policies for Growth and Competitiveness", Lexington Books.

Jacquemin, A. (1983), Industrial Policies and the Community in Coffey, P., Nijhoff, M. (ed.), Main Economic Policy Areas of the EEC.

Tyson, L., Zysman, J. (1983), “American Industry in International Competition: Government Policies and Corporate Strategies".

Johnson, Ch. (1984), "The Idea of Industrial Policy”, in Johnson, Ch., "The Industrial Policy Debate".

Graham, H. (1986), "European Industrial Policy", Croom Helm, London.

Geroski, P.A (1989)., European Industrial Policy and Industrial Policy in Europe, Oxford Review of Economic, 5.

Krugman, P., Obstfeld, M. (1991), "International Economics Theory and Policy".

Chang, H.-J. (1984), “The Political Economy of Industrial Policy”, St Martins's Press.
"Industrial policy may be generally defined as any government measure, or set of measures, to promote or prevent structural change."

Industrial policy includes "everything which is useful to improve growth and competitive performance"

Industrial policy "has to specify and solve the problems of structural change in the economy. Its task is to create optimum conditions for the necessary structural transformations to be carried out."

"Industrial policy ... means government policy aimed at or motivated by problems within specific sectors."

"Industrial policy means the initiation and coordination of governmental initiatives to leverage upward the productivity and competitiveness of the whole economy and of particular industries in it."

"Industrial policies referrer to those policies intended to affect in some ways manufacturing or service industries."

Industrial Policy is "wide-ranging, ill assorted collection of micro-based supply initiatives which are designed to improve market performance in a variety of occasionally mutually inconsistent ways."

"Industrial policy is an attempt by a government to encourage resources to move into particular sectors that the government views as important to future economic growth."

Industrial policy is one "aimed at particular industries (and firms as their components) to achieve the 
Table 2 (continued)

Sharp, M. (1998), "What is Industrial Policy and Why is it Necessary?", Prepared for TSER project No PL97 1059 on Science, Technology and Broad Industrial Policy.

Foreman-Peck, J., Frederico, G. (1999), European Industrial Policy: The Twentieth-Century Experience, Oxford University Press.

Beath, J. (2002), "UK Industrial Policy: Old Tunes on New Instruments?", Oxford Review of Economic Policy, 18(2).

Rodrik, D. (2004), Industrial Policy for the TwentyFirst Century, CEPR Discussion Paper, (4767).

Aiginger, K., Sieber, S. (2006), “The Matrix Approach to Industrial Policy", International Review of Applied Economics, 20(5), p. 573-603.

Saggi, K., Pack, H. (2006), "Is There a Case for Industrial Policy? A Critical Survey", The World Bank Research Observer, 21(2).

Esteban, J., Stiglitz, J., Lin, Y. J. (Eds.) (2013), The Industrial Policy Revolution II, Africa in the Twenty-first Century, Palgrave Macmillan, London.

Friesenbichler, K. Peneder, M. (2016), "Innovation, competition and productivity in developing countries", Economics of Transition, 24 (3), pp. 535-580.

Peneder (2017), "Competitiveness and Industrial Policy: From Rationalities of Failure Towards the Ability to Evolve", Cambridge Journal of Economics, 41(3), pp. 829-858. outcomes that are perceived by the state to be efficient for the economy as a whole."

Narrow concept "Industrial policy is often restricted to policies about subsidies." Broad concept ....... as any policy affecting the allocation of resources to industry and in this sense embraces both macroeconomic policy ... as well as the more traditional areas of microeconomic policy."

Industrial policy is "every form of state intervention that affects industry as a distinct part of the economy."

Narrow view: "Restrict attention to policies that target particular firms and industrial sectors." Broad view: "any policy that shapes or influences the competitiveness of a country's firms and industries

Uses the term industrial policy for "restructuring policies in favour of more dynamic activities generally, regardless of whether those are located within industry or manufacturing per se."

Industrial policy is the activity which creates a favourable environment for European business in general, the manufacturing sector and its industries in specific

interventions ... that attempts to improve business environment or to alter the structure of economic activities, towards sectors, technologies or tasks .....that .....offer better prospects for economic growth or societal welfare

governmental policies targeted at sectoral allocation of the economy....including... innovation and R\&D....infrastructure...education. ...integration of markets..., enduring stability and financial policies

The interplay of market forces, technology and productivity in developing countries resembles that of industrialized nations.

...interventions to foster industrial development, i.e. ....ability to evolve in accordance with a society's long-term rise of living standards

\section{References}

Aghion, Ph., Boulanger, J., Cohen, E. (2014) Rethinking industrial policy, Bruegel Policy Brief No 04

Aiginger K (2007) Industrial policy: a dying breed or a re-emerging phoenix, special issue on the future of industrial policy. J Ind Compet Trade 7(3+4, December 2007):297-323

Aiginger, K (2013a) The 'greening' of industrial policy, EurActiv, 21 May 2013

Aiginger, K. (2013b) The "greening" of industrial policy, headwinds and a possible symbiosis, WWWforEurope Policy Paper no 3, Vienna, Brussels

Aiginger K (2014) Industrial policy for a sustainable growth path. In: Bailey D, Cowling K, Tomlinson P (eds) New perspectives on industrial policy. Oxford University Press, 2. April 2015, Oxford, pp 365-394

Aiginger, K. (2016) New dynamics for Europe: reaping the benefits of socio-ecological transitionTransition, Vienna, Brussels 2016, http://Synthesis-Summary.foreurope.eu 
Aiginger, K. (2017) Towards a European Partnership Policy (EPP) with the south and the east - fostering dynamics, fighting root causes of migration, Policy Crossover Center, Working Paper 3/2017

Aiginger, K. (2019a) Industriepolitik, Europa von A-Z, Springer 2019 (forthcoming)

Aiginger, K, (2019b) Populism and Economic Dynamics in Europe, Policy Crossover Center: Vienna-Europe, Policy Paper, 1., Vienna. https://static1.squarespace.com/static/5780d6f1579fb375af56974a/t/5c877d5a1905 f4dea81e777f/1552383324903/PP+1-19.pdf

Aiginger, K. Firgo, M. (2017) Regional competitiveness: connecting an old concept with new goals, in Handbook of Regions and Competitiveness. Contemporary theories and perspectives on economic development, Huggins; R., Thompson, P. (eds), pp.155-191. UK, USA: Edward Elgar Publishing Altmaier, P. (2019) National Industry Strategy 2030, Federal Ministry for Economic Affairs and Energy, Berlin, Germany. https://www.bmwi.de/Redaktion/EN/Artikel/Industry/nationale-industriestrategie-2030.html

Aiginger, K., Handler, H. (2017) Europe taking the lead in responsible globalization, Policy Crossover Center, Economics Discussion Paper

Aiginger K, Sieber S (2006) The matrix approach to industrial policy. Int Rev Appl Econ 20(5):S. 573-S. 603

Aiginger, K., Bärenthaler-Sieber, S., Vogel, J. (2013) Competitiveness under new perspectives, WWWforEurope Working Paper no 44

National Industry Strategy 2030, Federal Ministry for Economic Affairs and Energy, Berlin, Germany. https:/www.bmwi.de/Redaktion/EN/Artikel/Industry/nationale-industriestrategie-2030.html

Block F, Keller M (eds) (2011) State of innovation: the U.S. Government's role in technology development. Paradigm Press, New York

BMWI (2019) A Franco-German Manifesto for a European industrial policy fit for the 21st Century https://www. bmwi.de/Redaktion/DE/Downloads/F/franco-german-manifesto-for-a-european-industrial-policy.pdf? blob=publicationFile \&v=2

Bofinger, P. (2019) Industrial policy: is there a paradigm shift in Germany and what does this imply for Europe? Social Europe, 27 May, https://www.socialeurope.eu/industrial-policy-in-germany

European Commission (2010) An integrated industrial policy for the globalisation era putting competitiveness and sustainability at Centre stage. COM, Brussels, p 614

Friesenbichler, K., Peneder, M. (2016) Innovation, competition and productivity. Economics of Transition 24(3): 535-580

McGillivray, F. (2004) Privileging industry: the comparative politics of trade and industrial policy. Princeton UniversityPress

Mosconi F (2015) The new European industrial policy: global competitiveness and the manufacturing renaissance. Routledge, Abingdon

Peneder M (2017) Competitiveness and industrial policy: from rationalities of failure towards the ability to evolve. Camb J Econ 41(2017):829-858

Pianta, M, Lucchese M, Nascia L (2016) Progressive Industriepolitik: industriepolitische Perspektiven https://oxiblog.de/progressive-industriepolitik-gesellschaftliche-prinzipien/

Reinstaller, A, Reschenhofer, P. (2019) The impact of the scope of technological search on path dependence in export specialization, Industrial and Corporate Change, December 2019, 28(6):1611-1635

Reinstaller, A., Unterlass, F. (2019) Diversification patterns at the regional level, in Kristensen, Dubois, Teräs (Hrsg.), Strategic approaches to regional development, Routledge, London, New York

Rodrik, D. (2004) Industrial policy for the twenty-first century CEPR Discussion Paper no 4767

Rodrik D (2014) Green industrial policy. Oxf Rev Econ Policy 30(3), Autumn 2014):469-491

Rodrik, D. (2016) Premature deindustrialization, J Econ Growth, 21(1)

Rodrik, D., Sabel, Ch.F. (2019) Building a good jobs economy, Working Paper. Copy at http://j.mp/2G5tnvX

Rubio, M. (2019) 2025 and the Future of American industry. U.S. Senate Committee on Small Business \& Entrepreneurship. https://www.rubio.senate.gov/public/_cache/files/0acec42a-d4a8-43bd-8608-a3482371 f494/262B39A37119D9DCFE023B907F54BF03.02.12.19-final-sbc-project-mic-2025-report.pdf

Stiglitz, J.E., Lin, J.Y., Patel, E. (2013) The industrial policy revolution II - Africa in the twenty-first century, Palgrave Macmillan

Warren, E (2019) Defend \& create American jobs. https://medium.com/@teamwarren/a-plan-for-economicpatriotism-13b879f4cfc7

Wigger, A. (2018) The new EU industrial policy: authoritarian neoliberal structural adjustment and the case for alternatives, Globalizations, 16(3), pp.353-369.

Publisher's Note Springer Nature remains neutral with regard to jurisdictional claims in published maps and institutional affiliations. 


\section{Affiliations}

\section{Karl Aiginger ${ }^{1,2} \cdot$ Dani Rodrik $^{3}$}

1 Policy Crossover Center: Vienna-Europe, Rotenhausgasse 6 (ÖGfE), 1090 Vienna, Austria

2 Vienna University of Economics and Business, Welthandelspl. 1, 1020 Vienna, Austria

3 Harvard Kennedy School, 79 J.F. Kennedy Street, Cambridge, MA 02138, USA 